\author{
Marcin Moskalewicz, Jan Zamojski \\ Uniwersytet Medyczny w Poznaniu \\ moskalewicz@gmail.com, janzam@interia.pl
}

\title{
KONTEKST FILOZOFICZNO- -ANTROPOLOGICZNY FUNKCJONOWANIA POJĘCIA CZASU W FILOZOFII MEDYCYNY: DYSKURSY NIEŚMIERTELNOŚCI, TERAŹNIEJSZOŚCI ORAZ WIECZNOŚCI
}

\section{Wprowadzenie}

Nasz tekst nie będzie próbą syntetycznego przedstawienia całości relacji między filozofią medycyny i historią medycyny a pojęciem czasu i przedmiotem tego pojęcia. Nie będzie też próbą szczegółowej analizy jakiegoś wybranego poglądu filozoficzno-medycznego. Będzie on raczej krótkim przedstawieniem kilku stanowisk, które uznaliśmy za interesujące i reprezentatywne dla omawianego zagadnienia, należących do trzech wyróżnionych przez nas poniżej „dyskursów czasu” w filozofii medycyny dyskursu nieśmiertelności, teraźniejszości oraz wieczności.

Najogólniej rzecz biorąc, pojęcie czasu pojawiało się w filozofii medycyny lub za jej sprawą bądź w kontekście metodologicznym czy epistemologicznym (którym nie będziemy się tutaj szczegółowiej zajmować), bądź - już w towarzystwie takich pojęć, jak nieśmiertelność, czas przeżywany czy wieczność - w kontekście antropologiczno-filozoficznym, który stanowić będzie przedmiot niniejszego szkicu. Wyrazistym przykładem dociekań w pierwszym z tych kontekstów są poglądy epistemologiczne i propozycje metodologiczne najwybitniejszego przedstawiciela polskiej szkoły filozofii 
medycyny, Władysława Biegańskiego (1857-1917), a zwłaszcza jego koncepcja prewidyzmu, zgodnie z którą istotą poznania naukowego jest przewidywanie $^{1}$. Z kolei kontekst filozoficzno-antropologiczny obfituje $\mathrm{w}$ wiele wątków dotyczących na przykład przedłużania młodości, powstrzymania procesu starzenia, nieśmiertelności, nieśmiertelności w wiecznej młodości, subiektywnego przeżywania czasu czy sensu życia wobec śmierci. W połączeniu z medycyną cechuje go obszerność problematyki związanej już nie tylko z zadaniem przedłużania życia - które towarzyszyło i towarzyszy człowiekowi (może z pominięciem tych z nas, którzy cechują się nasileniem zachowań autodestrukcyjnych) od bardzo dawna i właściwie na co dzień, poprzez dietę, postawy prozdrowotne (tak jak je historycznie rozumiano) oraz prawie wszystkie procedury medyczne - lecz także z zagadnieniami zaburzeń doświadczenia czasu czy metafizycznego wymiaru relacji lekarza i pacjenta. $W$ artykule proponujemy ujęcie owej obszernej problematyki związanej z kontekstem filozoficzno-antropologicznym funkcjonowania pojęcia czasu w filozofii medycyny okresu nowoczesności i ponowoczesności w ramy trzech dyskursów - nieśmiertelności, teraźniejszości oraz wieczności.

\section{Dyskurs nieśmiertelności}

Pierwszy dyskurs - nieśmiertelności - dotyczy relacji pacjenta i lekarza, jak i działań samego pacjenta. Celem jest tu przede wszystkim zapobieżenie śmierci pacjenta. Zapobieganie to ma miejsce $\mathrm{w}$ sytuacjach, w których istnieje przekonanie, iż śmierć nastąpiłaby za szybko, nie jest nieuchronna, a interwencja lekarska może otworzyć przed pacjentem perspektywę dalszego życia. Wiążą się z tym dylematy bioetyczne dotyczące między innymi problemu uporczywej terapii czy eutanazji biernej.

Pojęcie czasu $\mathrm{w}$ tym dyskursie wiąże się także $\mathrm{z}$ wydłużaniem życia ludzkiego, które nie jest zagrożone, poprzez różnego rodzaju procedury służące podniesieniu jego jakości (w tym te stosowane przez samego pacjenta), a także - gdy dobiega ono kresu - poprzez procedury podtrzymujące

\footnotetext{
${ }^{1} \mathrm{O}$ czasie w tej koncepcji por. W. Biegański, Teorya poznania ze stanowiska zasady celowości, Warszawa 1915, s. 213, 217, 219-220. Szerzej o polskiej szkole filozofii medycyny por. Polska szkota filozofii medycyny. Przedstawiciele i wybrane teksty źródtowe, red. M. Musielak, J. Zamojski, Poznań 2010, a o pojęciu filozofii medycyny np. J. Zamojski, Dlaczego wciąż warto badać polska myśl filozoficzno-lekarska, w: Polska szkoła..., op. cit.; A. Kapusta, Filozofia zdrowia, w: Podstawy interdyscyplinarności w naukach o zdrowiu. Poznawcza tożsamość dyscyplin badajacych socjokulturowy wymiar zdrowia i choroby, red. M. Skrzypek, Lublin 2014; J. Sak, Wielowymiarowość postrzegania zdrowia i choroby w kontekście przekonań zdrowotnych i poczucia sensu życia, Lublin 2012.
} 
życie, w nadziei, że nadejdzie taki moment w rozwoju medycyny, gdy możliwe będzie uleczenie schorzenia uznawanego dziś za nieuleczalne. $\mathrm{W}$ tym sensie zapobieganie śmierci i wydłużanie życia są dwiema stronami tego samego dyskursu nieśmiertelności. Tego rodzaju postępowanie charakterystyczne jest, jak zauważa Zygmunt Bauman, właśnie dla ponowoczesności, w której po raz pierwszy pojawiła się taka technologiczna możliwość ${ }^{2}$. Pisze o nim w kontekście filozoficzno-medycznym także Andrzej Szczeklik w książkach Kore ${ }^{3}$ i w Nieśmiertelności ${ }^{4}$, choć warto zauważyć, że widzi jego dwa rodzaje: pierwszy związany jest $\mathrm{z}$ wydłużaniem życia osobniczego, gdzie „kres, choć nieostry, majaczy gdzieś na horyzoncie”, drugi - ze znacznie trwalszym życiem poza organizmem, z hodowlą linii komórek rakowych czy też z tkankami hodowanymi in vitro, w przypadku których twórca tej metody, Alexis Carrel, pisał „o życiu wyjętym spod władzy czasu” i o „nieśmiertelności" 5 .

Zygmunt Bauman w tekście Medycyna, informatyka i życie wieczne wyróżnia dwie historyczne strategie starań $\mathrm{w}$ celu realizacji zadania osiągnięcia „bytu wiecznego": zbiorową, poprzez „większe całości” o dłuższym żywocie niż jednostkowy („Kościół, Naród, Partia”), i jednostkową, nakierowaną na pozostanie w zbiorowej pamięci poprzez indywidualne zasługi. Obydwie te strategie burzy nowoczesność, a ponowoczesność dokonuje dekonstrukcji już nie śmierci, a nieśmiertelności, zacierając granicę „między tym, co trwałe, a tym, co przejściowe" 6 . Warto zauważyć przy okazji, że to zatarcie granic, zgodnie z którym - posługując się nomenklaturą współczesnego czeskiego filozofa Vladimíra Šilera7 - dzisiejszy dyskurs medyczny i dyskurs opieki koncentrują się wokół sztuki życia - ars vivendi, wywołuje jednocześnie potrzebę ponownego wyodrębnienia i uczynienia częścią dyskursu medycznego sztuki umierania - ars moriendi. Zagadnienie to - tak jak widzi je Šiler - zostaje poszerzone o problematykę eugeniczną $w$ przypadku ars vivendi oraz - $\mathrm{w}$ przypadku ars moriendi - o problematykę związaną $\mathrm{z}$ eutanazją, zwłaszcza w pierwotnym jej znaczeniu ${ }^{8}$.

2 Z. Bauman, Medycyna, informatyka i życie wieczne, w: idem, Ponowoczesność jako źródto cierpień, Warszawa 2000, s. 266.

3 A. Szczeklik, Kore. O chorych, chorobach i poszukiwaniu duszy medycyny, Kraków 2007, s. 211-229.

${ }^{4}$ Idem, Nieśmiertelność. Prometejski sen medycyny, Kraków 2012.

${ }^{5}$ Idem, Kore..., op. cit., s. 266-268.

${ }^{6}$ Z. Bauman, op. cit., s. 274.

7 V. Šiler, Ars vivendi - ars moriendi, czyli o sztuce życia i sztuce umierania, tłum. E. Zamojska, w: Filozofia medycyny $w$ Czechach i na Stowacji, red. M. Petrů, J. Zamojski, J. Kuře, M. Musielak, Poznań 2012, s. 221-229.

8 Ibidem, s. 221-223 i 229. 
Jednym z bardziej rozpoznawalnych przedstawicieli dyskursu nieśmiertelności i obecnej w nim strategii wydłużania życia jest obecnie Aubrey de Grey (1963-), propagator biogerontologii, którego idee można interpretować jako utopijną próbę radykalnego przekształcenia czasowych ograniczeń ludzkiego życia, a jednocześnie - między innymi ze względu na „medialność" ich autora oraz recepcję jego poglądów - jako wyraz tęsknot za nieśmiertelnością, obecnych $\mathrm{w}$ dzisiejszej, zmedykalizowanej kulturze popularnej. De Grey - informatyk i biotechnolog oraz „naukowy celebryta” twierdzi mianowicie, że człowiek, który dożyje tysiąca lat, nie tylko już się narodził, ale jest obecnie po pięćdziesiątce. Tego typu poglądy o długości życia głoszono już w starożytności - wystarczy przypomnieć, że według Starego Testamentu Adam miał żyć 930 lat, a potomkowie jego i Ewy co najmniej kilkaset - zaś samego de Greya uznać można za kontynuatora poszukiwań średniowiecznych alchemików dążących do odkrycia tak zwanego eliksiru życia. Nie twierdzi on bowiem jedynie, że radykalne wydłużanie życia jest dzisiaj możliwe, ale że dysponujemy zasobami wiedzy, technologii i środków finansowych umożliwiającymi zapobieganie procesowi starzenia jako takiemu, a problemem jest przede wszystkim właściwa relokacja istniejących zasobów ${ }^{9}$. Kwestia ta ma - zdaniem de Greya - wymiar przede wszystkim mentalny i polega na powszechnym przyzwoleniu na starzenie się, które jest uznawane za "naturalne”, w mocnym sensie tego słowa. Sam autor - prowadzący, jak sam to określa, globalną krucjatę przeciwko starzeniu się - twierdzi, rozwijając wolnorodnikową teorię starzenia z lat 50. autorstwa Denhama Harmana, że kluczem do sukcesu jest powstrzymanie uszkodzeń DNA mitochondrialnego zachodzących za sprawą metaboli$\mathrm{zmu}^{10}$.

Fantazje de Greya nie są zupełnie oryginalne i wpisują się doskonale w ponowoczesne praktyki transhumanizmu. Sam de Grey należy do ruchu krionicznego, zapoczątkowanego przez Roberta Ettingera (1918-2011) i postulującego zamrażanie ciał $\mathrm{w}$ ciekłym azocie ${ }^{11}$. Inny współczesny amerykański transhumanista i futurysta walczący z procesem starzenia, Raymond Kurzweil (1948-), poza stosowaniem ścisłej diety, spożywa 150 tabletek dziennie - nie jest to już po prostu promocja zdrowego trybu życia, lecz próba ekstremalnego programowania zdrowia, w której dążenie do powstrzymania starzenia idzie $\mathrm{w}$ parze $\mathrm{z}$ narcystycznymi marzeniami o nie-

${ }_{9}$ A. de Grey, M. Rae, Ending Aging: The Rejuvenation Breakthroughs That Could Reverse Human Aging in Our Lifetime, New York 2007.

${ }^{10}$ A. de Grey, The Mitochondrial Free Radical Theory of Aging, Austin 1999.

${ }^{11}$ R. Ettinger, The Prospect of Immortality, Garden City 1964. 
śmiertelności ${ }^{12}$. Do popularności tego rodzaju idei bez wątpienia przyczynia się medialny sposób prezentowania sukcesów nowoczesnej medycyny. Jednak idee te, gdyby miały się ziścić, rodzą wiele problemów nie tylko natury metafizycznej, ale także społeczno-politycznej. W jaki sposób wpłynie to na nasze postrzeganie sensu życia i jego poszczególnych etapów? Jak współistnienie kilkunastu pokoleń zmieni strukturę społeczną? Czy „nieśmiertelność" służyć będzie tylko (wybranym) jednostkom, czy stanie się dobrem wspólnym?

\section{Dyskurs teraźniejszości}

Opuszczając poziom współczesnego medycznego science-fiction, przyjrzymy się - na przykładzie sensu oraz funkcjonowania pojęcia czasu $\mathrm{w}$ tradycji psychiatrii fenomenologicznej, zwanej też niekiedy egzystencjalną - drugiemu z wyróżnionych przez nas dyskursów - dyskursowi teraźniejszości. Pojęcie czasu w dyskursie teraźniejszości jest niejako odwrotnością pojęcia stanowiącego przesłankę przedstawianych wyżej poglądów, w tym sensie, że wszystkie one przyjmują, iż człowiek jest przedmiotem w c z a s i e. Psychiatria fenomenologiczna z kolei, idąc na przekór duchowi zmatematyzowanego przyrodoznawstwa, zakłada, że jest on pod$\mathrm{m}$ i o t e m c z a s u. Nieśmiertelność - $\mathrm{w}$ sensie przedłużenia życia i zapobiegania śmierci - nie jest $\mathrm{w}$ tej tradycji obecna, zaś klasycznie rozumiane przedłużenie życia w czasie obiektywnym jest bardzo często przedmiotem krytyki. Prezentowane przez przedstawicieli tego kierunku koncepcje dotyczące czasu przeżywanego (ang. lived time; fr. temps vécu; niem. erlebte Zeit), formułowane przede wszystkim w kontekście chorób psychicznych, są ufundowane są na przekonaniu, że - po pierwsze - czas ma znaczenie nie tylko ściśle filozoficzne, ale także diagnostyczno-terapeutyczne, oraz - po drugie - że kryterium niezdrowego podejścia do czasu - a więc takiego, z którym należy terapeutycznie walczyć - jest zablokowanie jego „wewnętrznego rozwoju" (używając nomenklatury egzystencjalnej: zaburzenie stawania się), mogące skutkować niekiedy temporalną „śmiercią” za życia.

Spośród licznych przedstawicieli rzeczonej tradycji zwrócimy uwagę na sens czasu obecny w dziele trzech reprezentantów jej pierwszego pokolenia - Ludwiga Binswangera (1881-1966), Viktora Emila von Gebsattela (1883-1976) oraz Erwina W. Strausa (1891-1975) - właśnie w odniesieniu do 2004.

12 R. Kurzweil, T. Grossman, Fantastic Voyage: Live Long Enough to Live Forever, Emmaus 
wspomnianych zaburzeń stawania się. Pominiemy przy tym, skądinąd istotne, niuanse ich koncepcji - Binswanger był z całej trójki najbliższy psychoanalizie i analityce egzystencjalnej wczesnego Martina Heideggera, von Gebsattel logoterapii Viktora Frankla i teologii katolickiej, zaś Straus antropologii fenomenologicznej - skupiając się na poglądzie wyznaczającym płaszczyznę zgody pomiędzy nimi.

Pojęcie dyskursu terán niejs zości stosujemy z tego względu, iż pojęcie czasu, którym operują wspomniani autorzy (zmedykalizowane pojęcie filozoficzno-antropologiczne, różne od pojęcia fizykalistycznego), jest związane istotowo z fenomenem subiektywnego przeżycia. Czas przeżywany posiada nie dwa, lecz trzy wymiary - przeszłość, teraźniejszość i przyszłość - które niejako współistnieją w ramach tak zwanej rozciągniętej teraźniejszości w taki sposób, że każda chwila posiada swój wymiar przeszłościowy, teraźniejszy i przyszły. Co niezwykle istotne, czasu przeżywanego wspomniani autorzy nie pojmują w czysto "duchowy” czy "abstrakcyjny" sposób, lecz - także z tego względu, że wszyscy byli lekarzami - jako fenomen ucieleśniony i mający podstawę $\mathrm{w}$ samym procesie życia. Proces ten posiadać ma swój "świadomościowy” komponent, który nie jest oderwany od świata doświadczeń i interakcji z innymi, lecz przezeń zapośredniczony. $\mathrm{W}$ tym sensie czas jako proces witalny i czas jako przeżywana historyczność stanowią dwie strony tego samego medalu ${ }^{13}$. Czas ten jest jednocześnie czasem płynącym naturalnie ku przyszłości - posiadającej wiele możliwości, z których zaledwie część zostanie zrealizowana, a przy tym zawsze niepewnej; wyznaczającej jednak horyzont doświadczenia mający znaczenie dla przeżywanego "tu i teraz".

Zarówno studia Binswangera nad manią i schizofrenią ${ }^{14}$, badania Strausa nad depresją i zaburzeniami obsesyjno-kompulsywnymi15, jak i analizy von Gebsattela dotyczące melancholii i zachowań nałogowych ${ }^{16}$ zakładają takie właśnie pojęcie czasu. Istota wglądu, o który nam tutaj chodzi, polega na tym, że tak rozumiany czas może ulec zarówno spowolnieniu, jak i przyspieszeniu, niezależnie od czasu obiektywnego płynącego cierpliwie w jed-

${ }^{13}$ E. Straus, Geschehnis Und Erlebnis. Zugleich Eine Historiologische Deutung Des Psychischen Traumas Und Der Renten-Neurose, Berlin - Heidelberg - New York 1978.

14 L. Binswanger, Ausgewählte Werke. Band 4. Der Mensch in Der Psychiatrie, red. A. Holzhey-Kuhn, Heidelberg 1994.

${ }^{15}$ E. Straus, Das Zeiterlebnis in Der Endogenen Depression Und in Der Psychopatischen Verstimmung, "Monatsschrift Für Psychiatrie Und Neurologie” 1928, LXVIII, s. 640-656; idem, On Obsession. A Clinical and Methodological Study, New York 1948.

${ }^{16}$ V.E. von Gebsattel, Prolegomena Einer Medizinischen Anthropologie, Berlin - Göttingen Heidelberg 1954. 
nostajnym rytmie następujących po sobie chwil. Przypadkiem granicznym wyznaczającym popadnięcie w stan psychotyczny - jest sytuacja całkowitego zatrzymania czasu, "temporalna próżnia” - by użyć określenia Strausa polegająca na zablokowaniu możliwości życia (stawania się), niezależnie od obiektywnie płynącego czasu odmierzanego przez zegar ${ }^{17}$. Taka zablokowana czasowość stanowić ma wspólny mianownik licznych zaburzeń, a więc niejako określać głębszy poziom jednoczący partykularną symptomatologię, gdy tymczasem czas "zdrowy" to czas swobodnie płynący ku przyszłości. Jak wspomnieliśmy wyżej, ponieważ pojęcie czasu, którym operują wspomniani autorzy, jest niejako odwrotnością pojęcia używanego $\mathrm{w}$ dyskursie nieśmiertelności, czas zdrowy to tutaj nie tyle czas "długi” (wyznaczający dłuż s z e ż y c i e ), lecz czas przeżywany jako ro z c i ą g n i ę t y k u przyszłości, posiadający horyzont umożliwiający życie pojmowane jako wewnętrzne (osobowe) stawanie się. Analogiczne przeżycia spowolnienia przepływu czasu bądź zawężenia horyzontu oczekiwań występują, w chorobach (w czasie obiektywnym) "przewlekłych”.

\section{Dyskurs wieczności}

Trzeci dyskurs, w którym obecni są filozofowie medycyny dyskurs wieczności, ma właściwie charakter teologiczny. Wieczność jest w nim jednym z atrybutów Boga (czy też bytu najwyższego), który włączany jest do rozważań filozoficzno-medycznych jako element mniej czy bardziej zwartego systemu poglądów w tej dziedzinie. W formacji nazywanej polską szkołą filozofii medycyny tak jest u Henryka Nusbauma; w poznańskiej myśli filozoficzno-medycznej - u Heliodora Święcickiego; w tradycji psychiatrii fenomenologicznej - u Viktora Emila von Gebsattela; współcześnie zaś u wspomnianego już Andrzeja Szczeklika.

Henryk Nusbaum (1849-1937) był pierwszym polskim lekarzem, który wykładał filozofię medycyny jako odrębny przedmiot, był on też autorem pierwszego podręcznika z tej dziedziny. Uznając cierpienie za najważniejsze zjawisko w życiu człowieka, niemal całe życie poszukiwał jakiegoś uzasadnienia dla tego fenomenu. Choć był ewolucjonistą, a poglądy swoje nazywał „monizmem naukowym” (w dzisiejszej nomenklaturze pewnie najstosowniejsze byłyby tu określenia: materializm przyrodniczy czy redukcjonizm),

\footnotetext{
17 Odnośnie do tej tezy zob. M. Moskalewicz, Disturbed Temporalities. Insights from Phenomenological Psychiatry, „Time \& Society” 2015, http://dx.doi.org/10.1177/0961463X15577257 [dostęp: 26.06.2016 r.].
} 
wyraźnie nie zamierzał poprzestać na czysto biologicznym i behawiorystycznym stanowisku, zgodnie z którym cierpienie to wypracowana przez ewolucję reakcja organizmu na zagrożenie i zarazem ostrzeżenie przed nim. Zarówno to, jak i jego krytyczne stanowisko wobec filozofii Nietzschego, Lutosławskiego i dzieł literackich Przybyszewskiego stały się przesłankami napisania rozprawy Czem jestem, w której zawarł rozdziały poświęcone czasowi i temu, co nazwał „niepojętą świętością"18. Bóg pojawia się w tej rozprawie jako możliwy przedmiot wątpienia, byt, w który zwątpić można pod wpływem cierpienia, lecz i jako nieskończona wiedza i bezgraniczna świadomość, nieograniczona pamięć, nieograniczona zdolność przewidywania: „W świadomości Bożej cała przeszłość i cała przyszłość jest ześrodkowaną w teraźniejszość". Dodatnią formą świętości jest miłość, ma ona swoje źródło w bycie, który Nusbaum nazywa Wszechmiłością i który jest tożsamy z Bogiem. Wszechmiłość jest przyczyną współczucia, a także między innymi dobra i poznawania prawdy, podczas którego objawia się ona nam; jest też przyczyną ewolucyjnego prawa przystosowania. W tym przypadku byt najwyższy ze swymi atrybutami, w tym wiecznością (aeternum), jest obiektywną podstawą powszechnego prawa moralnego, z którego wynikają dla Nusbauma takie zadania terapii, jak „odwracanie tuż zagrażającej śmierci” i usuwanie choroby. Natomiast na pytanie o istotę zjawiska cierpienia Nusbaum znajduje odpowiedź poprzez konwersję - w jego odczuciu to chrześcijaństwo umożliwia znalezienie dla cierpienia uzasadnienia $\mathrm{w}$ transcendencji i uzasadnienie jego istnienia $\mathrm{w}$ świecie ${ }^{19}$.

Z zupełnie innych przesłanek wychodził Heliodor Święcicki (1854-1923), lekarz ginekolog i pierwszy rektor Uniwersytetu Poznańskiego. W swoim wystąpieniu $O$ estetyce $w$ medycynie ${ }^{20}$, które zamykało obrady zjazdu lekarzy i przyrodników polskich w Krakowie w 1911 roku, Święcicki nie tyle usiłował uzgodnić prawa ewolucji z teologią, dochodząc w efekcie do takiego czy innego obrazu Boga, ile czynił Boga punktem wyjścia swoich rozważań, odwołując się zresztą w sferze filozofii do zupełnie innych źródeł niż Nusbaum i pozostali reprezentanci polskiej szkoły filozofii medycyny spod zaborów rosyjskiego i austriackiego, bo głównie do polskiej recepcji heglizmu w myśli Karola Libelta. Bóg jest sprawcą, a poprzez swoją wieczność - także gwarantem harmonii świata, najwyższym artystą. Lekarz to Jego pomocnik, ktoś, kto każe tańczyć sferom organicznym „wedle rytmu i muzyki wyzna-

${ }^{18}$ H. Nusbaum, Czem jestem, Warszawa 1901, s. 29-33, 49-57.

19 Szczegółowiej o teologicznych aspektach filozofii medycyny H. Nusbauma por. J. Zamojski, System filozofii medycyny Henryka Nusbauma, Poznań 2006, s. 109-114.

${ }^{20} \mathrm{H}$. Święcicki, O estetyce w medycynie, w: Księga Pamiątkowa XI Zjazdu Lekarzy i Przyrodników Polskich w Krakowie 18-22 Lipca 1911, Kraków 1912. 
czonej im z góry". Lekarz to artysta, "prawa ręka Stwórcy”, a ponieważ "choroba przedstawia sobą stan estetycznie niepiękny", lekarz winien ten stan odmieniać21. Bardzo podobne motywy (obok licznych światopoglądowych odniesień) znaleźć można w późniejszej o dziewięćdziesięciolecie twórczości Andrzeja Szczeklika, gdzie dopuszcza on myśl o wieczności muzyki, jednej ze sztuk odgrywających dużą rolę terapeutyczną: „Niektórzy badacze - w oparciu o porównania śpiewu ptaków, wielorybów i ludzi podejrzewają istnienie jednego, platońskiego świata muzyki, czekającego na odkrycie" 22 .

Zagadnienie czasu i nieśmiertelności pojawia się u Święcickiego w jeszcze jednym kontekście. Odwołując się do wskrzeszenia przez Jezusa córki Jaira, Święcicki nazywa Jezusa Mistrzem i Lekarzem, a samo wskrzeszenie „wspaniałym, niedościgłym wzorem dla lekarza”. To lekarz „zwiastuje pacjentowi słowa zbawcze: «Wstań, weźmiej łoże twoje i chodź», jest więc tym razem nie tyle "prawą ręką Stwórcy», ile tym, kto przynosi nowinę o wyzdrowieniu"23. Nasycenie rozprawy Święcickiego tego typu językiem wzięło się naszym zdaniem zarówno z jego głębokiej religijności, jak i z niemożności uporania się $\mathrm{z}$ traumą po utracie bardzo przezeń kochanej żony, której nie zdołał uratować $\mathrm{z}$ zapalenia płuc.

Wieczność pojawia się w spuściźnie Święcickiego w jeszcze jednym kontekście - jako cel życia, w przeciwieństwie do „spraw naszych”, czyli błahych spraw życia codziennego, „na które trwonimy zdrowie”24.

$\mathrm{Z}$ kolei w dziele wspomnianego już wyżej niemieckiego psychiatry i fenomenologa Viktora Emila von Gebsattela wieczność - a konkretnie rzecz biorąc: odniesienie do pozaczasowej transcendencji - stanowi podstawową metafizyczną przesłankę konstytuującą właściwą relację terapeutyczną pomiędzy lekarzem a pacjentem ${ }^{25}$.

W ujęciu von Gebsattela odniesienie do pozaczasowej transcendencji jest warunkiem możliwości autentycznej pomocy medycznej. Autor przedstawia relację osoby cierpiącej i osoby niosącej jej pomoc, posługując się modelem,

${ }^{21}$ Ibidem, s. 73 i 61.

22 A. Szczeklik, Katharsis. O uzdrowicielskiej mocy natury i sztuki, Kraków 2003, s. 88.

${ }^{23}$ H. Święcicki, op. cit., s. 65. Szczegółowiej o rozprawie Święcickiego por. J. Zamojski, Heliodor Święcicki i jego rozprawa "O estetyce w medycynie", w: Heliodor Święcicki w 90. rocznice powstania Uniwersytetu Poznańskiego, red. M. Musielak, Poznań 2009, s. 108-128; J. Barański, J. Zamojski, Heliodor Święcicki, w: Polska szkoła..., op. cit., s. 219-234; M. Musielak, Heliodor Święcicki (1854-1923), Poznań 2013, s. 132-137.

${ }^{24}$ A. Wrzosek, Modlitwa jest oddychaniem w Bogu. O modlitewniku Heliodora Święcickiego i jego religijności (fragmenty), „W Drodze” 1994, nr 11, s. 101-102.

${ }^{25}$ Zob. przede wszystkim: W.E. von Gebsattel, Zur Sinnstruktur der ärztlichen Handlung, w: idem, Prolegomena..., op. cit., s. 361-378. 
w którym relacja ta zostaje podzielona na trzy poziomy. Poziomy te reprezentują zachodzące podczas spotkania modyfikacje relacji pomiędzy lekarzem a chorym. Poziom pierwszy to poziom polegający na wołaniu potrzebującego o pomoc - wołaniu człowieka do człowieka - $\mathrm{i}$ jest on poziomem najbardziej bezpośrednim ${ }^{26}$. Poziom drugi jest poziomem obiektywizacji, poziomem diagnostyczno-terapeutycznym, na którym następuje wzajemne wyobcowanie partnerów - jeden $\mathrm{z}$ nich staje się lekarzem, drugi uprzedmiotowionym przypadkiem choroby. Najważniejszy jest jednak poziom trzeci, będący punktem dojścia relacji. Spotykają się na nim dwie osoby i dwóch równych partnerów. By jednak spotkanie to było możliwe - i tym samym by relacja lekarza i pacjenta mogła przybrać swoją ostatecznie pożądaną postać - konieczne jest właśnie odniesienie do tego, co transcendentne. Już po zakończeniu technicznych aspektów procesu leczenia, w obliczu siły wyższej pacjent i lekarz stają wobec siebie jako partnerzy - równi w obliczu winy, cierpienia i skończoności.

Von Gebsattel uważa, że jedynie na gruncie chrześcijaństwa można wykształcić taką relację partnerstwa pomiędzy lekarzem a pacjentem - relację wykraczającą poza instrumentalną i skuteczną pomoc medyczną. To Chrystus afirmujący cierpienie ma sprawiać, że pomiędzy dwoma podmiotami powstaje wyższa, transcendentna wspólnota, a pomoc medyczna zostaje podniesiona do rangi metafizycznej27. Pomijając owo bezpośrednio religijne odniesienie, które w sytuacji realnego spotkania klinicznego może stanowić potencjalne zagrożenie dla autonomii światopoglądowej pacjenta, w koncepcji tej chodzi przede wszystkim o podkreślenie wagi owej relacji metafizycznie zakorzenionego partnerstwa. Pojęcie pozaczasowej transcendencji nie jest zresztą używane przez von Gebsattela jako pojęcie czysto religijne, lecz jako pojęcie medyczne ${ }^{28}$. Jego nowy sens jest wprawdzie głównie teoretyczny, ale ma być także drogowskazem dla codziennej praktyki lekarskiej, w której nieunikniony jest kontakt $\mathrm{z}$ cierpieniem i bezradność wobec rzeczywistości śmierci.

${ }^{26}$ Można tu zauważyć analogię z myślą Lévinasa, zgodnie z którą „źródłowe otwarcie na tego, kto może pomóc [...], ustanawia antropologiczną kategorię opieki medycznej jako kategorię pierwotną, nieredukowalną, etyczną"; E. Lévinas, Cierpienie bezużyteczne, tłum. M. Kowalska, „Literatura na Świecie” 2004, nr 1-2, s. 404.

${ }^{27} \mathrm{~W}$ tym z kolei można widzieć pewne analogie zarówno z myślą Henryka Nusbauma, jak i Heliodora Święcickiego.

28 Por. M. Moskalewicz, Die Sprache der Philosophie und Theologie im Dienste der Medizin (am Beispiel einiger psychiatrischer Begriffe von Ludwig Binswanger und Viktor Emil von Gebsattel), w: Medizin und Sprache - die Sprache der Medizin, red. E. Brinkschulte, F. Dross, A. Magowska, M. Moskalewicz, P. Teichfischer, Frankfurt am Main 2016, s. 167-181. 


\section{Zakończenie}

Zaprezentowane wyżej przykłady nie wyczerpują, rzecz jasna, bogactwa znaczeniowego i funkcjonalnego pojęcia czasu w filozofii medycyny - ukazują jedynie jego trzy charakterystyczne wymiary. Zauważmy jednocześnie na koniec, że pominięty przez nas kontekst metodologiczno-epistemologiczny jest tym, w którym pojęcie czasu pojawia się we współczesnej filozofii medycyny najczęściej - i to w swojej najbardziej ortodoksyjnej, fizykalistycznej formie - a mianowicie pojmowany jako miara służąca na co dzień badaniom klinicznym.

\section{Philosophical and Anthropological Context of the Notion of the Time in Philosophy of Medicine: Discourses of the Immorality, the Present, and the Eternity}

\section{Summary}

This paper gives an overview of three discourses of time in philosophy of medicine distinguished by the authors: the discourse of immortality (aiming at an objective prolongation of life), the discourse of the present (aiming at the quality of subjective temporal experience) and the discourse of eternity (aiming at transgressing the limits of temporality). Views of renowned representatives of each of these discourses are being discussed, including members of the so-called Polish School of Philosophy of Medicine (H. Nusbaum, H. Święcicki), phenomenological psychiatrists (L. Binswanger, V. E. von Gebsattel, E. Straus) as well as some more contemporary authors (Z. Bauman, A. de Grey, A. Szczeklik).

Słowa kluczowe: psychiatria fenomenologiczna, transcendencja, czas przeżywany, polska szkoła filozofii medycyny, pacjent

Keywords: phenomenological psychiatry, transcendence, lived time, Polish School of Philosophy of Medicine, patient

DOI: $10.14746 /$ cbes.2016.15.2 